\title{
Dealing with corruption in South African civil society: Orientating Christian communities for their role in a post-apartheid context
}

\begin{abstract}
Author:
Friedrich W. de Wet ${ }^{1}$

Affiliation:

${ }^{1}$ Unit for Reformed Theology and the Development of the South African Society, North-West University, Potchefstroom Campus, South Africa
\end{abstract}

\section{Correspondence to:}

Fritz de Wet

Email:

fritz.dewet@nwu.ac.za

Postal address:

Private Bag X6001,

Potchefstroom 2520,

South Africa

\section{Dates:}

Received: 29 Sept. 2014

Accepted: 30 Mar. 2015

Published: 28 May 2015

How to cite this article: De Wet, F.W., 2015, 'Dealing with corruption in South African civil society: Orientating Christian communities for their role in a post-apartheid context', Verbum et Ecclesia 36(1), Art. \#1388, 11 pages. http://dx.doi.org/10.4102/ ve.v36i1.1388

\section{Note:}

This work is based on research supported wholly by the National Research Foundation of South Africa (Grant Number 91018). Any opinion, finding and conclusion or recommendation expressed in this material is that of the author and the NRF does not accept any liability in this regard.

\section{Read online:}

Scan this QR
code with your
smart phone or
mobile device
to read online.

The way in which the full spectrum of Christian communities are challenged to realign themselves in addressing the impact of corruption on the contemporary South-African society can be a relevant indicator of civil society's state and functionality in a post-apartheid democratic context. Utilising the interpretative and normative tools of practical-theological research, the researcher attempts to point out markers for Christian communities towards orientating themselves regarding their role in a complex landscape and in an asymmetrically shaped public sphere. The discussion includes an analysis of the current shape of civil society, an interpretation of the complex landscape of perceptions regarding corruption and an overview of the dilemmas faced by some of the major Christian church traditions in the post-apartheid South African context concerning their truthful presence in civil society. The discussion concludes by making a case for the need to anchor the realignment of the prophetic voice and the revitalisation of the transformative presence in a profound and far-reaching theological reorientation. Tension fields that involve critical and constructive action in a situation of endemic corruption cannot be negotiated without ridding the own presence from potential corruptive elements like hidden exclusivity, half-hearted concern and compromise.

Intradisciplinary and/or interdisciplinary implications: Making use of the interdisciplinary results of social sciences and civil-society studies, the author provides an overview for Christian communities and their leaders in theologically orientating themselves for an appropriate angle of approach in entering the public sphere with a view on authentic and impactful participation in anti-corruption dialogue and actions. The key finding of the research amounts to the following: Tension fields that involve critical and constructive action in a situation of endemic corruption cannot be negotiated without ridding the own presence from potential corruptive elements like hidden exclusivity, half-hearted concern and compromise.

\section{Introduction}

The prevalence of corruption seems to have a direct and immediate impact on stability in African democratic environments (Chabal \& Daloz 1999:106). The strain of corruption is immediately felt in fragile systems where democratic consolidation is still in an unsettled state. The unsettled state of South Africa's post-apartheid democratic dispensation, for example, is indicated by factors like growing poverty and income inequality, dominance by one party, the ineffective management of health-care services, an ineffective deployment of the developmental role of education and lacking service delivery in the post-apartheid era (cf. Kuperus 2011:280). In such a fragile system, corruption - as a means of relocating public sources for private enrichment or with the purpose to gain coercive power over people (cf. Hyslop 2005:776) - can become one of the final straws that break the camel's back.

Corruption is seen as a crucial issue in the South-African society. It is an issue that is urgently in need of critical and remedial action. Therefore, the way that Christian leaders deal with their role in addressing this issue can be a relevant indicator for the robustness and openness of the civil-society platform in this particular democratic context. Initial research of the interpretative dimension in a practical-theological take ${ }^{1}$ on this problem field included key questions like the following: Why is corruption seemingly impacting significantly on the democratic stability of the

\footnotetext{
1.Baker and Reader (2009:228) envisage a practical-theological take on civil society that is both interdisciplinary and multilayered, working simultan (20usly at the intersections of a number of key political, cultural and to full dynamism and comp and describe Chistian interaction as a movement between the public and the private, the global and the local, the secular and the sacred, the creative (with risk involved) and the painful (with the predicament of being contested involved), the resurrection and the crucifixion. In doing so, an attempt is made to resist the simplistic and partial analysis of contemporary life that opts for engagement with only one or other side of the binary pole.
}

Copyright: @ 2015. The Authors. Licensee: AOSIS OpenJournals. This work is licensed under the Creative Commons Attribution License. 
South-African society? What does the tension field created by corruption and anti-corruption rhetoric or action reveal about the readiness of civil society to play an authentic role in significant change? It became clear that we are confronted by a complex problem field and that no simplified, onedimensional answers can be provided in orientating Christian communities for the consideration of their role in civil society when it comes to addressing corruption issues creatively and responsibly.

An attempt is made in this article to provide a basic orientation for Christian communities and their leaders by reflecting on perspectives from social sciences and civil-society studies regarding the state of civil society and its potential role in anti-corruption dialogue and actions in the post-apartheid democratic context. Being a practical-theological study, ${ }^{2}$ the focus will ultimately be on the theological dimension of the tension field created when Christian communities have to shape or re-shape their critical or constructive contribution in an ever-changing public forum that may present itself to be open or closed to a lesser or greater degree. Hermans (2005) expresses one of the key questions that surface in this dynamic practical-theological tension field as follows:

On the one hand one needs to be truthful to normative claims of a religious community and tradition; but on the other hand one needs to be involved in an open dialogue with persons who do not share the metaphysical ground of this claim. How can one sail between Scylla of being strongly distinct but publicly irrelevant and Charybdis ${ }^{3}$ of being relevant but to relinquish its distinct truth claim? (p. 219)

The lines for this envisaged re-orientation is drawn by:

- reflecting on the concept of civil society in democratic contexts with the dynamics in the post-apartheid South African civil society as culmination-point

- interpreting the complex landscape of corruption in the South African context

- considering and interpreting the consequences of the dilemmas and challenges faced by some of the major Christian church traditions in the post-apartheid context concerning their truthful presence in civil society

- identifying initial theologically rooted factors that Christian communities and their leaders will need to reckon with in shaping or re-shaping their roles towards stabilising and developing the post-apartheid South African democracy in the face of potentially destabilising factors like corruption.

2.My practical-theological take on the research field of civil society comprises a vantage point of focusing on the theological dimension of the underlying tension field in which human actions are embedded. This vantage point will lead the researcher to ask questions like the following: In what sense are a person's actions or hesitance to act embedded in notions about God's presence in the space of civil society? In what sense are a person's actions or hesitance to act anchored in faith notions about God's purpose for society, a sense of responsibility in communicatin God's will and a sense of humility in realizing the own limitations and history of errors in communicating this will of God authentically and truthfully (cf. Immink 2005:21-42; Pleizier 2010:4, 5)

3.The name pair Scylla and Charybdis originated in Greek mythology and came to be used as a reference to a situation in which two dangers are aligned in such a way that the risk of avoiding the one increases the risk of falling into the other. In Greek mythology, Charybdis was a sea monster who attacked ships when they tried Greek mythology, Charybdis was a sea monster who attacked ships when they tried
to negotiate the narrow channel between her cave and the whirlpool Charybdis (Oxford Dictionaries n.d)

\section{Civil society in the development of a democratic environment}

Before I proceed with an interpretation of the role played by Christian religious communities in the current SouthAfrican democratic landscape, I shall briefly reflect on the concept of civil society and its function in the inception and development of a democratic environment.

According to Fioramonti and Fiori (2010:86), it was only after the mass mobilisations in the late 1980s and early 1990s that civil society was catapulted into the spotlight of democratisation studies. Civil society came to be seen as an essential element in promoting political liberty, preparing the way for democratic reform and improving the quality of democracy. The conscious development of a public sphere within which civil society organisations can enter into dialogue with the state was increasingly seen to form an important ingredient in the formation of a new political culture following a constitutionally based transition to democracy (cf. Kaarsholm 2009:411).

Regarding religion's possible role in civil society, notable developments took place during the same period. After the Second World War, the development of societies was largely undertaken from a modernist vision for a secular state. Religion was seen as part of a culture that promotes particularity, not compatible with ideas of progress towards a free, inclusive and open society in which liberal citizenship can thrive. Political rationality and faith could coexist peacefully alongside each other as long as religion was limited to the private sphere (Führding 2013:129). This situation, however, changed remarkably in the course of the 1990s. The unmistakable role played by churches in processes of establishing solid democracies and furthering development received growing acknowledgement. Religious leaders were increasingly invited to political forums and were accepted as role players that could enhance the quality of deliberations on issues like poverty reduction and service delivery (Burchardt 2013:36-37; cf. De Freitas 2005:24).

Regarding the contribution of civil society towards the development of a democratic society (especially as it seems in post-colonial contexts), potential participants need to take into account that they are entering a multi-faceted and complex action field. Kuperus (2011:281) demarcates the ideal of a critical as well as a constructive role for civil society in democratic consolidation by visualising a civil society that tries to uphold an autonomous relationship with the state, that nurtures civility, that holds state institutions responsible for what has been entrusted to them and that provides an empowering environment for marginalised groups. In praxis, the public sphere in which civil society functions in post-colonial contexts proved to be no tension-free and unproblematic space. The original Habermasian idea of the public sphere as 'Öffentlichkeit' (a public landscape that is characterised by openness and free debate) proved to be a narrow ideal type. This became clear as the praxis 
of engagement in the public sphere of developing or postcolonial democratic societies (as it became clear in the case of post-apartheid South Africa) revealed that it was not necessarily homogeneous entities that were brought together in engagement and that these entities were not necessarily free to interact with each other on a level playing ground. In contexts where openness were compromised by imbalanced power structures and interest-driven formations, a shared 'public sphere' were criticised for providing little beyond ideology, the monopolisation of the 'public' realm by privileged elites or its absorption for the purposes of consumerism and commercialisation (Kaarsholm 2009:412; cf. Zalanga 2010:48).

In South Africa, as Fioramonti and Fiori (2010:94) point out, the ruling ANC government initially considered trade unions and community-based organisations that pioneered the struggle against apartheid as major assets in democratising and developing society. The overall approach adopted by the post-apartheid South-African government, based on the philosophy of 'the developmental state', however, gradually resulted in a more subdued and ambivalent stance toward civil society. On the one hand, government still considered civil-society organisations as essential partners in furthering the country's development. On the other hand, government essentially began to understand these organisations as mere instruments for the purpose of implementing government policies. There was a growing reluctance from government's side to visualise a role for these organisations as independent actors that were free to influence decision making or could play a constructive role in critiquing policies (cf. Lehman 2008:118).

The implications of this narrowed and ambiguous conceptualisation of the role of civil society in the democratisation of South Africa are far-reaching. The dynamics and complexities that religious communities have to face when considering a responsible and optimal point of entry into this asymmetrically shaped sphere ${ }^{4}$ will be the object of our discussion in the rest of the article. This discussion will commence by referring to the complexities involved in defining a constructive role for holding a government accountable regarding corruption and the threat it poses for democratic stability. Then we will proceed by outlining the dilemmas faced by some of the major Christian church traditions in the post-apartheid context concerning their truthful presence in civil society and the implications of the position in which they find themselves for dealing with corruption in the public sphere. The discussion will conclude by identifying some key theologically rooted factors with which religious communities (with the focus on Christian traditions in the case of this article) will need to reckon in defining their future role towards stabilising and developing

\footnotetext{
4.It is particularly challenging to create space for productive tension between civil society and state in an asymmetrically shaped environment. If the boundary society and state in an asymmetrically shaped environment. If the boundary between the two is pushed too far in the favor of state, civil society could lose its rightful place. If the boundary is pushed too far in the favor of civil society, the state could come to a fall under chaotic forces. In an ideally shaped democratic society, civil society requires government to survive whilst it remains important for the stat to draw on the strengths of civil society (De Freitas 2005:29).
}

the South African democracy in problem fields like those that have to deal with the potentially destabilising effects of corruption.

\section{The complex landscape of corruption in Africa, especially as it manifests in post-apartheid South-African society}

Mbaku (2007:12), points out two types of corruption that are closely linked, especially in Africa and other developing societies, namely political and bureaucratic corruption. Bureaucratic corruption has to do with the misappropriation of public funds for private benefit. Political corruption has to do with the undermining of laws with the purpose of benefitting certain political parties. Political corruption can also be aimed at assisting politicians to obtain or retain leadership positions, forming an illegal nexus of money and politics in the process. In many African countries, those individuals or groups which have captured political power often use that power to generate benefits and privileges for themselves and their supporters (cf. Ahrens 2011:28).

In an attempt to explain the high occurrences of corruption in African context, the cultural argument is often deployed in a polarising way. 'Continuists', on the one hand, claim that corrupt behaviour is endogenous in nature, deeply rooted in African culture. On the other hand, 'rapturists' claim the exteriority of corrupt behaviour, which they identify as definitely modern and coinciding with the introduction of the colonial way of doing things into Africa. In this polarising debate, culture is either seen as the ultimate cause of corruption, or it is seen as the victim of an external force by which it has been perverted. From the one end of the spectrum, the modern state is seen to be subject to a corruptive influence by traditional culture (contrasting the supposed honesty and decency of 'first-world' mentality over against its 'third-world' counterpart). From the other end of the spectrum, traditional culture is seen to be subject to corruption by the advent of the modern state (corruption is then condemned as a foreign element caused by the selfenriching behaviour of the privileged accompanied by the implementation of capitalism) (Hyslop 2005:776; Blundo \& De Sardan 2006:26).

Rather than taking an 'either-or' point of departure in this debate and creating an opportunity for blame shifting in the process, the intricate network of co-producing factors should be reckoned with in explaining the prevalent climate for corrupt behaviour in African context.

Regarding exterior factors (with reference to the capitalist culture imposed on South-African society by the colonial heritage, corporate-business enterprise and apartheid rule), clear instances of corruption became evident towards the end of white rule. When people realised that the end of white dominance was imminent, there was a flurry of activity in trying to gain as much personal benefit as possible before the window of opportunity was finally closed. President FW De 
Klerk had to close down the Department of Development Affairs (DDA) in 1991 after the Pickard commission concluded that it was permeated by corruption and that public-service officials thought that they were going to miss out if they did not make the most of a last opportunity to help themselves (Hyslop 2005:784). After the inception of the new democratic dispensation under the ANC government, a clear line could be drawn between new instances of corruption and the old homeland administrations from which the new system emerged (Naidoo 2013:525).

Endogenous factors also seem to play an important role in creating a climate for corruption. As Chabal and Daloz (1999:99) remark, there appears to be a clear reluctance in Africa to adhere to the abstract norms of the legalbureaucratic order that lies at the heart of Western polities. Traditional African thinking does not necessarily place corruption in a watertight frame for regulating and dividing what is right from what is wrong. This allows corruption to become endemic as it forms an intrinsic part of the social sphere of life, relatively acceptable and relatively visible. With the eye on making progress in life, people from all levels of society need to play their part in chains of mutually beneficial relationships and need to have access to favourable opportunities for material gain. Corruption is, therefore, not seen to be a matter of a few 'rotten apples' and even less as an 'evil' to be terminated by lively 'ethical' campaigns.

In a study on the popular semiology of corruption in Africa (based on interviews pertaining the symbolic, ideologically inclined and argumentative landscape of corruption in Benin, Niger and Senegal), Blundo and De Sardan (2002:111-119) found a continuous alternation between condemnation (stigmatisation) and tolerance in the normative discourse on corruption. The discourses surrounding stigmatisation proved to be closely associated with political rhetoric in a context of lobbying for a change of government. All changes from one government to another seemed to involve a rapid increase in such discourses. A number of changes in government by means of coups d'état were justified by the apparent desire to eradicate corruption. It also seemed that those forces that opposed existing governments made extensive use of this register. In contrast, justifying and legitimising discourses of corruption in everyday practices seemed to be justified according to a rhetoric of corruption as a means of taking 'one's due' and 'good manners'. The primary arguments for the justification of corruption included some 'grand utterances' in which corruption was sometimes considered to be a matter of recovery - of what is 'one's due' (being compensated for a suffering, which the perpetrators believe themselves to have been subjected to). At other times, accepting compensation from the user who wishes to express thanks for the service rendered was seen to be a case of 'good manners' - confirming the endemic nature of corruption in African culture.

Focusing on the patterns of corruption that are in the process of emerging in the post-apartheid South-African landscape, it becomes clear that severe challenges will have to be faced by civil society in dealing with this issue.

According to Hyslop (2005:786), perceptions regarding corruption in the post-apartheid political landscape were influenced by the ANC's notable shift in ethos from propagating a strict socialism in the mid-1980s to embracing the economic success of a new black elite by the mid-1990s. Under Mandela, and to a larger degree under Mbeki, government policies encouraged black entrepreneurs to take advantage of state contracting and the opportunities posed by corporate ownership. These policies seemed to create a climate in which the lines between legal means of benefitting from rent seeking and outright corruption were increasingly blurred. High-profile ANC members became increasingly open to the idea of accepting material compensation for their political contributions during the struggle years.

According to Fioramonti and Fiori (2010:96), widespread disgruntlement with the government's economic policy in the second part of the 2000s turned into political infighting. The criticism of trade unions and other leftist groups were used by certain groups within the ruling elite to challenge President Mbeki at the ANC's National Conference in December 2007, effectively forcing him to step down in the second half of 2008. In the emergence of these internal rival groups, personal loyalty rather than shared ideological beliefs seemed to play a predominant role, paving the way for the sound establishment of neo-patrimonial politics in the ruling party (Lodge 2014:1). Socio-economic elements like the redistribution of wealth and poor service delivery came to be the burning issues at a populist level, turning the attention of the masses away from the critique against the morality of Mbeki's successor, Jacob Zuma. A culture of entitlement, rather than a culture of deeply rooted morality seemed to surface predominantly in these circumstances. It is noticeable that very few civil society protest actions, apart from a few that were organised by middle-class groups, have occurred against President Zuma demanding that he be held accountable for the corruption and rape charges against him (Fioramonti \& Fioro 2010:96).

In an interview with David Lewis, head of Corruption Watch (a privately funded watchdog organisation based in Johannesburg), the Public Prosecutor's report concerning the R246 million upgrade of Zuma's private home in Nkandla is discussed. According to Lewis, the National Prosecutor's report advised that Zuma should apologise, that he should cover the costs of some of the upgrades that were made to his Nkandla home and that he should report back to parliament within a period of two weeks. When the indicated date arrived he allegedly submitted a letter to Parliament's Speaker, maintaining that the findings of the report did not correspond with a cabinet investigation, which made it clear that he was not involved in any wrongdoing. Incidents like these, according to Lewis, make people bolder to partake in acts of corruption if they begin to sense that leaders are seemingly getting away with these acts of self-enrichment. 
The impression can be created that politically connected people can count themselves to be immune against prosecution (Nkandla in the wind 09 July 2014).

\section{The dilemmas and challenges faced by notable Christian traditions concerning their role in post- apartheid civil society}

According to the data of South Africa's 2001 population census, ${ }^{5} 79.8 \%$ of the population claimed to be Christian at the time of the census. Of these, $32.6 \%$ indicated that they adhered to mainline traditional churches, 5.9\% indicated their affiliation to be Pentecostal or charismatic, and $31.8 \%$ indicated affiliation with African Independent Churches. Hindus, Muslims, Jews, Buddhists and members of traditional African belief systems together constituted just below $5 \%$ of the population. An estimated $15 \%$ of the population indicated that they did not adhere to any particular religion (Statistics South Africa 2004:24).

An interpretation of the 2001 population census by Hendriks and Erasmus $(2005: 105,106)$ shows a progressive decline in the membership of mainline denominations and a growing trend in the numbers of those members who counted themselves as members of the African Independent and Pentecostal traditions. This is a pattern that seems to correspond with Christianity'soverall profilein theGlobalSouth(cf.Hendriks \& Erasmus 2001:63; Rule 2007:420; Vorster 2013:151).

Although the 2011 census estimated the population at 51.8 million people, this particular data set did not include statistics on the religious demography of the country.

Data from a 10-country survey of Pentecostals conducted by the Pew Research Centre's Forum on Religion and Public Life in 2006, ${ }^{6}$ however, provide the following estimates regarding the religious affiliation of South Africa's urban population, confirming the ongoing nature of the basic trends that were gleaned from the 2001 data. See Figure 1.

Kuperus (2011:279) observes that the involvement of Christian churches in the public sphere of the post-apartheid era seems to be far more diverse and less binary than it was during the pre-democratic period. During the apartheid years, the Dutch Reformed Church (DRC), as primary member of the traditional Afrikaans reformed churches in South Africa, saw its task to be the conscience of the government and consequently played the role of a virtual state church in actively providing justification and protection for the

5.It should be noted that statistics derived from sources like census data and polls have their caveats and do not provide refined information. The official South African state census cannot be expected to reflect the actual participatory element of livin church membership as the discrepancy between national census data and statistics of church denominations on ground level points out (Vorster 2013:149).

6.The Pew Research Center's Religion and Public Life Project, launched in 2001 presents itself as a project that seeks to promote a deeper understanding of issues prest the itsel a at the intersection of religion and public affairs. A survey for Pew Forum's project, Spirit and power: A 10-country survey of Pentecostals, was conducted in South Africa from 11 to 27 May 2006 amongst 800 respondents (The Pew Forum n.d.).

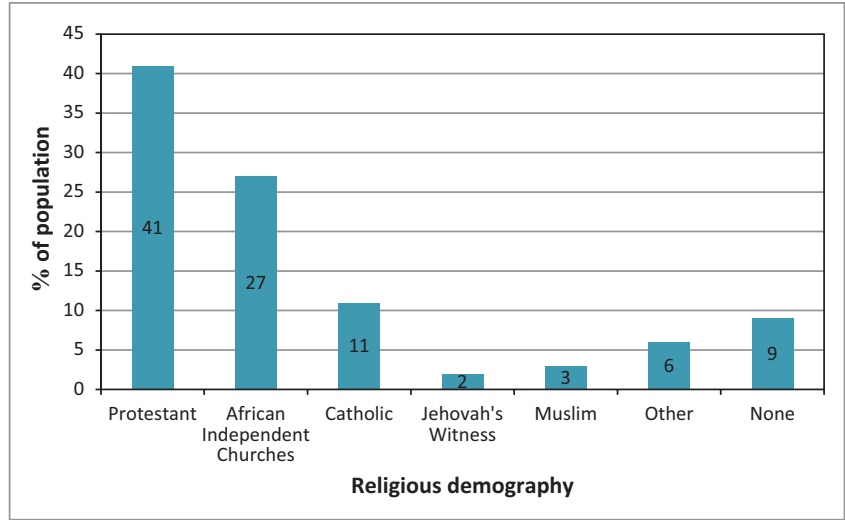

Source: The Pew Forum, n.d., viewed 04 July 2014, from http://www.pewforum.org/2009/04/ 23/religion-in-south-africa-15-years-after-the-end-of-apartheid/

FIGURE 1: South African religious demography according to the 2006 Pew Forum study.

apartheid state (cf. Coertzen 2008:785-788). In contrast, the ecumenical Protestant grouping dominated by the Englishspeaking mainline denominations formed the South African Council of Churches (SACC) and played a decisive (prophetic) role in the apartheid years, positioning themselves as a major platform for initialising the anti-apartheid struggle during the 1980s. The African Independent Churches (AICs), despite their significant numbers and influential presence in the South African society, did not formally organise themselves with a view on formal engagement in the political sphere.

In the post-apartheid era, the landscape changed dramatically and in various ways for these different traditions. They are now all challenged by the complexities involved in the current national government's conceptualisation regarding the role of religious communities in civil society.

We now proceed by giving an overview of major developments that these particular traditions will most likely need to deal with in the process of re-visualising their role in a post-apartheid civil society. In the case of the AICs, the focus will be on the Zion Christian Church (ZCC) as the largest representative of this particular tradition.

\section{The Dutch Reformed Church}

In the apartheid years, the traditional Afrikaans reformed churches, with the DRC as most prominent member, had a major impact on the way in which apartheid was legalised by the National Party government. Although the church saw its task as being the conscience of government by testing the whole of reality against the principles of Scripture (Coertzen 2008:779), it eventually used this position to uphold the ideology of Christian nationalism with its support of the state. Its language did not prove to be the passionate language of the prophet, demanding justice for all of South-Africa's people, but the careful reasoning of the court theologian (concentrating on justifying a privileged position for the Afrikaner people (Boesak 2005:144; cf. Theron 2008:232).

Kuperus (2011:284-288) summarises the position of the DRC in the post-apartheid era as not only having a more 
muted voice but also as being more divided today than it was during the apartheid era. After the end of apartheid, the DRC arrived at a point where the necessity for a reassessment of its nature, identity and its role in society was realised. The breakdown of apartheid and the deconstruction of its justification as a normative ideology caused the DRC to share the shame associated with this ill-fated experiment (Theron 2008:231).

In the post-apartheid context, the DRC found itself in a position of having a muted voice. Justifying apartheid from Scripture was revealed to be an act of misguidance and a case of sinful self-seeking at the expense of others. It led to incredulity and disillusionment amongst members of the church as well as society at large, especially regarding the credibility of the church as an authentic role-player in civil society (Theron 2008: 231; cf. De Villiers 2008:734).

A second aspect by means of which the DRC's struggle to come to terms with its contemporary identity and role in the post-apartheid public sphere is highlighted has to do with dividedness in theological thinking. A diversity of reformed, evangelical, liberal, post-modernist and post-foundationalist approaches seems to have a polarising effect on the perceived place of the church in the contemporary political landscape of South Africa. Two forms of public engagement, shifting from one to the other, have emerged from this polarising tension field: The DRC as 'preserver of the flock' (with addressing the vulnerability of its members as core motive) and the DRC as 'promoter of societal transformation' (with the purpose of getting to grips with its dwindling social clout) (cf. Theron 2008:236). In the 1990s, reluctance to deal with the implications of transformation and political change led the DRC church leadership to embrace the 'preserver of the flock' model.

The way in which the church expressed its views on social and political issues echoed the alarm of its membership regarding the unacceptably high incidence of crime, the perceived discrimination against members in the name of affirmative action and concerns about the Truth and Reconciliation Committee being too traumatic for the country. The 'preserver of the flock' model emphasises a kind of ministry that should focus on emotional healing and should strengthen the endurance of its members against the onslaughts of society (De Villiers 2008:736).

A change in leadership in the course of the 2000s urged the DRC to embark on a more inclusive form of engagement in the public sphere. As an example of this new turn, reference can be made to the DRC's proposals to parliament concerning changes to the Marriage Act as well as the proposed law that would enable civil unions for homosexual couples. Rather than presenting itself as a biblical defence for heterosexual marriage, the submission tried to reckon with the broad spectrum of views within society regarding the acceptability of homosexuality. The submission advised the government to maintain freedom of expression, including the religious freedom of churches that wishes to uphold a heterosexual

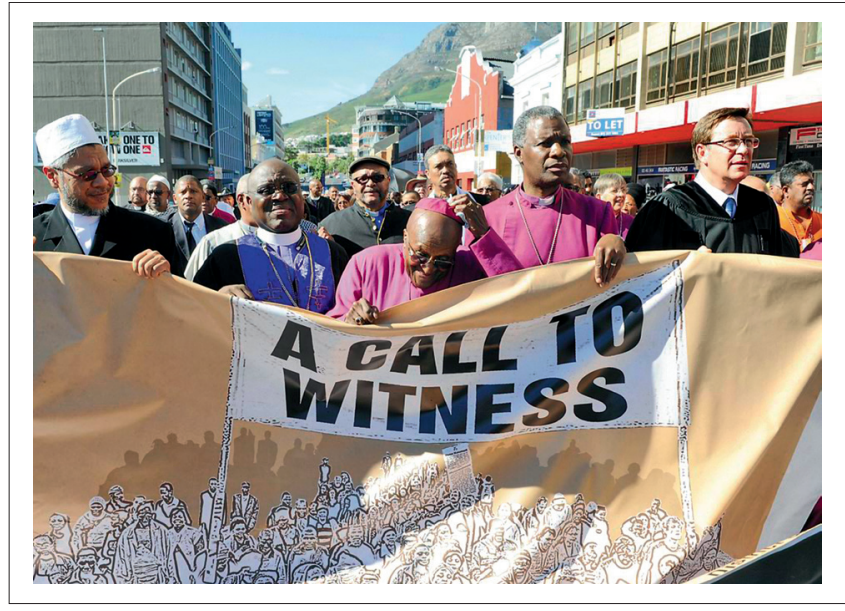

Source: Optog na parlement: Godsdiensleiers kap Zuma oor korrupsie, 2014, Die Burger, 20 April, viewed 16 August 2014, from http://www.dieburger.com/nuus/2014-04-20godsdiensleiers-kap-zuma-oor-korrupsie

FIGURE 2: Sheikh Igshaan Taliep (Muslim Judicial Council), Bishop Ziphozihle Siwa (Methodist Church), Emeritus-Archbishop Dr Desmond Tutu, Archbishop Thabo Makgoba (Anglican Church) and Dr Braam Hanekom (Dutch Reformed Church) during a march against corruption in Cape Town on 19 April 2014 (Optog na parlement Die Burger, 20 April 2014).

structure for marriage, in the course of drawing up the new bill. As another example of a more inclusive stance to public engagement, the DRC leadership partook in a multi-religious public protest march to parliament against corruption in April 2014, openly confronting President Zuma with allegations of corruption and calling for honesty, integrity and responsibility in national leadership (see Figure 2).

At the same time, it appears that the DRC leadership's perceived role in public engagement may still be determined by elements of the reclusive 'defender of the flock' position as it is expressed in reluctance to accept the Belhar Confession and in the reservations and conditions surrounding organic unity with the Uniting Reformed Church in Southern Africa (URCSA) $^{7}$ (cf. Strauss 2010:140; Kuperus 2011:284-288; Theron 2012). The counter productivity between inclusive and exclusive elements may prove to be one of the biggest challenges that leaders of the DRC have to face in the quest for finding a credible voice in the contemporary SouthAfrican public sphere.

\section{The ecumenical churches and the South African Council of Churches}

Unlike the reformed Afrikaans churches, the ecumenical churches, by means of their involvement in the activities of the SACC, ${ }^{8}$ played a prominent role in the opposition against apartheid. By the mid-1970s, church leaders like Desmond Tutu and Alan Boesak were gaining influence in the SACC and offered a prophetic voice. They emphasised the need for justice and the hope for liberation, incorporating

7.At a 2015 regional synod meeting of the DRC in the Northern Cape, (as reported on the web-page of the DRC in the Eastern Cape (Herderlike brief n.d.)) a possible
emendation of a church-order article that could have opened the possibility for congregations to the accept the Belhar Confession was rejected. With this resolution, this particular synod made it clear that the acceptance of Belhar cannot be unanimously viewed to function as an ultimatum for church unity with the URCSA.

8. For a brief history of the SACC and the theological influences that shaped its programs and principles, see Meiring (2010). 
even elements of radical Calvinism in the process (Meiring 2010:318). The role of the SACC in the 1970s and 1980s was critical and prophetic, speaking with a powerful, fearless and influential voice against apartheid, the theocratic state theology and the church theology of the 1980s (Pieterse 2000:83).

In a certain sense, the profile of the SACC in the contemporary South-African context still bears the characteristics of its distinct agenda during the apartheid years. Its advocacy for economic justice - for example, its persistent arguments against proposed arms deals and their potential impact on taking money away from urgent community development projects - demonstrates the continued commitment of the SACC to oppose unfair structures and to see to it that the rights of marginalised members of the society are not ignored (Kuperus 2011:290).

Morepredominantly, however, are patterns of marginalisation in the state of the SACC's public presence as manifested in an initial sense of 'arrived-ness' and a more lasting situation of having to deal with a diminished influence within the ANC.

A sense of 'arrived-ness' emerged in the circles off the ecumenical churches after the goal of dismantling the apartheid rule was achieved (Phiri 2001:137). Boesak (2005) voices this mode of thinking as follows:

Many of us, the descendants and remnants of the struggle tradition in the churches, regard the liberation movement as 'our' movement. The government is now 'our' democratically elected government. They epitomize our own political and personal achievements. The policies they espouse are the crystallised ideals we fought and sacrificed for. Or so we would like to believe. Besides, we do not want to be identified with what most of us consider hypocritical and unnecessary strident opposition politics. (p. 156)

Whilst the SACC has indeed played a supportive role in the democratically elected government's efforts at nation building (as was especially seen in the SACC's leading role in the Truth and Reconciliation Committee's activities), its resurfacing critical stance on issues pertaining to economic justice and corruption is an indication of the resilience of the SACC's 'watchdog' role. The SACC's insistence on reintroducing its critical, watchdog stance over and against the government may in fact be a crucial reason for the SACC currently being marginalised in ANC circles and brought under pressure to adapt to the national government's view on the church's role in furthering the causes of the 'national agenda' (Cochrane 2004:229; Kuperus 2011:293). In this regard, Boesak (2005:161) refers to an example of interaction between the national government and the SACC when then President Mbeki addressed the Triennial Conference of the South African Council of Churches in 2004. In Mbeki's address, the churches were called to join the government's agenda regarding the spirit of the traditional African social practice of letsema [volunteerism] and vuk'uzunzile [standing to do things for yourself]. The churches were called to affirm and join, in the spirit of volunteerism and self-help, avoiding the 'temptation' to see their role as one of 'watchdog' over the government, its politics and practices. The president was inviting them to merely accept what the government has already determined to be the 'national agenda' and not to critically help fashion the national agenda.

This pre-determined conformist role visualised for religion by the ruling party poses a serious challenge for a voice that - in the process of re-assessing its role - realises that it cannot but stay true to its prophetic roots.

\section{The African Independent Churches role as manifested in the Zion Christian Church}

The African 'Independent', 'Instituted', 'Indigenous' or 'Initiated' Churches (AICs), ${ }^{9}$ consisting of African-founded churches with a traceable embeddedness in both African traditional as well as Pentecostal roots, have grown significantly, comprising as much as $47.6 \%$ of black South Africans according to the 2001 census data (Hendriks \& Erasmus 2005:91). These churches trace their beginnings to two main origins, the first being secessions from mainline churches at the end of the 1800s and in the early 1900s and the second originating with the birth of Pentecostalism in South Africa (Hendriks \& Erasmus 2001:50; cf. Bongmba 2006:169). In terms of the representative power of its sheer size alone, this group has the potential to make a huge impact on civil society's participation in shaping the future of South Africa's young democracy. According to the numbers and percentages of the AICs as reflected in the 2001 census data, it was confirmed that the ZCC constituted the largest Church country wide, with 4.948 million members or $11 \%$ of the total population (Hendriks \& Erasmus 2005:97).

During the apartheid era, the ZCC seemed to distance itself from a possible critical role in politics. The ZCC was even seen as an organisation that uncritically affirmed the apartheid government by, for example, inviting government leaders to the ZCC's Moria headquarters for the annual Easter celebrations. In 1965, for example, the Minister for Bantu Administration and Development, M.C. de Wet Nel, was in attendance at the church's Easter gathering. The leader of the church, Bishop Edward Lekganyane, at that occasion took it upon himself to thank the white people for '... leading us out of the darkness.' Similarly, during the height of the apartheid years, P.W. Botha was invited to attend the ZCC's 1985 Easter celebration (Bompani 2008:667).

Kuperus (2011:300) assesses the ZCC's public presence in the post-apartheid era not to have undergone significant change. It still seems to remain nationally aloof. No direct engagement with macro-political events or dialogues in the forums of the national public sphere still seems to be the order of the

9.In South Africa, the Aics are commonly grouped into Ethiopians, Zionists and Apostolics. Ethiopianchurches were the first to an displayed anti-racist and Pan-Africanist tendencies whilst retaining the doctrines of the traditional Protestant churche appeared later (1917-1920). They have a Pentecostal character, emphasize healin and ask of their members to wear the official dress code of the church. Apostolic emerged from the 1940s onward and claim that the authority of their leaders are derived directly from Christ's Twelve Apostles (Venter 2004:198-199) 
day for the ZCC. This church is clearly not operating in the domain of publicly recognized expressions of civil society like non-governmental organisations or trade unions. The ZCC does not seem to consider it important to take a bold stance in the national public sphere. This stance can create the impression that we here have to do with a sleeping giant.

It has, however, been argued that the ZCC should find its strength in its possible influence on society from below and in the contribution it can make to a new, Africanized identity. AICs like the ZCC maintain trust and coherence amongst their membership by means of prescribing a highly disciplined lifestyle. Adherents are encouraged to maintain a strictly regulated lifestyle, abstaining from alcohol and drugs and honouring hard work, which are actors that could have a large impact on the social and economic mobility of South Africa's economy. Independent Christianity's role in the contemporary South-African landscape can thus be visualised to develop as a fluid, locally focused social movement, not striving to collectively endorse any particular political party. Rather, it is launching activism from a local point of departure in trying to establish relationships with local authorities with the view to assisting its membership in countering life-threatening issues like HIV and AIDS, corruption, crime, a lack of education, unemployment and ineffective service delivery (Bompani 2008:671; Cochrane 2004:228; Kuperus 2011:301).

AICs find themselves in the challenging tension field of consciously translating their local influence from below into an influential role in the organised dimension of civil society.

\section{The importance of identifying key theological factors for Christian engagement in the civil space of the contemporary South African society}

The foregoing overview of the tension fields in which major Christian traditions are findings themselves regarding their civil role in the contemporary South African society leads to questions like the following.

To what extent can the reformed tradition (as its presence is manifested for instance by the current position of the DRC) be enabled to break the shackles of its muted presence by being rid from its association with the discriminatory atrocities of the apartheid past? To what extent can a presence of credibility and integrity be secured by factors like polarisationconquering and exclusivist-eradicating unity amongst members of this tradition as well as a re-interpretation of its Reformational roots that is unquestioningly committed to a critical-constructive role for the benefit of all South Africans?

How can the Ecumenical tradition (as its participation is reflected in the efforts of the SACC) regain a prophetic voice that somehow navigates the tension field of the current national government's reluctance against opening itself up to critical voices aimed at the heart of the morality of its governance?
To what extent should the AICs be called upon to translate their large quantitative presence in the South-African society (as illustrated by the nationally aloof situation in which the ZCC finds itself) into an integrative qualitative presence in the organised public sphere?

It is important for these traditions and the organised efforts of the Christian communities that they represent to anchor their thinking theologically in negotiating the tension fields in which they find themselves and in re-orientating themselves with regard to their perceived role in the South-African civil society. Christian communities should realise anew that, in a society that seems to be dominated by secularisation, their belief in unchanging truth should not be seen as a factor that necessarily diminishes their impact but instead can be a key to their potential strength and growth in an age of alienation and change (cf. McMullen 2010:11). Some of the key theological factors that will have to be reckoned with include the following.

\section{Finding a credible voice in an unified presence}

Aligning themselves with Wolfgang Huber's theological theories concerning human dignity, Fourie and Van Rooi (2009:88-89) point out that the theme of human dignity as for instance expressed in unity between the different members of the DRC family of churches - cannot be viewed to be of formal importance alone. It should actually be seen as the primary portal for the church's public role in the SouthAfrican democratic environment. This particular church family cannot present themselves as propagators for unity in society without creating space for lived liberty in their own midst and 'creolizing' inherited religious traditions in the process (Konieczny, Lybarger \& Chong 2012:399).

The DRC can hardly expect the state to accept admonishments against its governance whilst the church still remains hesitant to associate with those family members who suffer most under exploitive elements in the system in which they find themselves. As long as members of the still predominantly white and economically privileged DRC stay pre-occupied with factors that threaten their own security and are not primarily focused on allegiance with family members amongst the more than $40 \%$ fellow South Africans who are terribly poor and suffer from exploitation, critical contributions in civil society will lack fundamental integrity (De Villiers 2008:741).

\section{Anchoring action in civil society in non-comprising, non-self-asserting Christian identity and transformative spiritual vitality}

Anchoring thinking in the Christian identity and the unique nature of the church, a balance should be found between receding, on the one hand, into a colonial style in which the own interest is elevated to be the only interest and, on the other hand, adapting to endogenous cultural elements to such an extent that the distinct Christian voice is lost. Both extremes will result in a corruptive presence 
in society. In this regard, Pieterse (2000) reminds us of the implications of the unique non-compromising but at the same time non-self-asserting identity of the church in its role in civil society:

The church is called to be a source of blessing in society, not to regulate it. We are called to be a church that is not an ecclesia domesticate (a domesticated church) but rather an ecclesia peregrinatione (a pilgrim church). We are called to be a church which, though it is of every age, people and group, will not find a resting place in any class, nation or epoch. (p. 95)

De Gruchy (2004:59) visualises an active role for the church in the transformation of the democratic South Africa that is not limited to what is humanly achievable in the here and now. The church will surely be predisposed to prefer a democratic society over against one that is totalitarian, but it should not primarily be concerned with legitimating democracy. Rather, its task is to provide a democratic system with a vision that will push its concern for humanity beyond its present scope towards a greater expression of what God has in mind for this world (cf. Coertzen 2008:792).

According to Bediako (2005:124), one of Africa's most important resources for the development of new redemptive public theologies may well be located in the distinct Christianspiritual vitality that is currently awaking in its communities. The African churches, however, faces its greatest challenge in trying to move their members in the direction of accepting and embracing the 'social' meaning of their religion. Part of what Christianity can contribute to the establishment of democratic cultures in Africa has to do with introducing 'the mind of Jesus' to the public sphere as a non-dominating, redemptive mind as this relates to the issues of power and authority. Without a conception of authority and power such as Jesus held, informing civil society and becoming rooted in the minds of those who seek political office, the hope of attaining the goal of a genuine democratic culture may prove to be elusive (cf. Zalanga 2010:58).

The task of conscientising Christian communities entails empowering members not to remain on the surface level of the problem field that is surrounding corruption and its destructive effect on society. Members will not merely be drawn into a culture of entitlement, protesting against the effects of corruption alone and demanding that the government do something for them. They will be equipped to discern the moral range and depth of what need to change in their own hearts and in their leaders' hearts on the deep level of the cause of corruption. A new heart and a new mind is needed that can only be actualised through participation in the redemptive mind of Christ. In this regard, a reassessment of the reformed tradition with its roots in a Calvinist worldview can play an important role in nurturing a critically informed and far-reaching visualisation for the role in society as a calling. As Bosch (1991:133) points out, there is something distinctly modern about the Calvinist view of life in the sense that it encourages its members to play an informed and constructive role in civil society. In the Calvinist paradigm, it is not only the ordained minister who is called. Rather everyone is called, everyone who, in gratitude and obedience, sees themselves called to serve in the world. Believers see themselves to be privileged as well as obliged to participate in the renewal of the face of the earth, taking responsibility for a far-reaching, critical-constructive role in society with the eye on the ultimate renewal for which it is destined.

\section{Directing the prophetic voice in a sensitive dialogical way}

In an asymmetrical democratic environment where the ruling party displays hesitancy to open itself to a critical voice from civil society, it can be a challenging task to make the prophetic voice heard in an impactful way. Although the prophetic voice is a bold and clear voice, confronting humanity right up to the core of its motives, existence and social responsibility, it never has a coercive or arrogant quality. Although the church has the distinct task of proclaiming the Gospel of the Kingdom of God, it does not do so by communicating in a disrespectful and intolerant way against the religious and ideological preferences of other institutions in society (Coertzen 2008:792-793).

Rather than merely directing the critical voice in a monological, threatening or prescriptive way, the possibility of critical dialogue should be considered. The rationality according to which the parameters for sophisticated constructive-critical debate in the public sphere are designed should include an element of sensitivity for the imbeddedness of dialogue partners in the intricacies of the African worldview and culture.

Ahrens (2011:34, 35) discusses the problematics involved in choosing an approach informed by a Western 'Ordnungsperspektive' as strategy for countering corruption in African context. The philosophy behind an 'order perspective' formulates formal rules that must be defined in a clear-cut way in terms of acts that should be allowed and acts that should be forbidden. The problem with this approach is that these rules do not automatically have contextual acceptability in all societies. An order-political line of thinking can lead to a moral prescription to African cultures (Ahrens 2011):

Ordnungspolitisches Denken kann nicht mehr darauf bestehen wollen, andere Länder den Kulturen des Westens angleichen zu wollen.WodasderFallist,erweistsichder Antikorruptionsdiskurs als Epiphänomen des Modernisierungsprojektes. Es ist anzuerkennen, dass westlicher Markt und westliches rationales Bürokratieverständnis nicht ohne weiteres zur traditionalen Kultur einiger Länder passen. [Order-political thinking cannot any longer base the premise for its existence on the presupposition that other countries should necessarily align themselves with Western culture. Where this is the case, the anti-corruption discourse turns out to be a subjective manifestation of the modernisation project. It should be understood that Western economical principles and Western rational understanding of bureaucracy simply do not fit in with the traditional culture prevalent in some countries.] (p. 35, [author's own translation]) 
Ahrens (2011) concludes his argument for sensitivity regarding the imbeddedness of dialogue partners in a nonWestern cultural context as follows:

Wenn Korruption erfolgreich eingedämmt werden soll, dann wird dies nur als Ergebnis lang anhaltender und notwendigerweise komplexer Kommunikations-prozesse gelingen, in denen die Freiheit der anderen und ihr Eingebundensein in eine andere Situation gewürdigt werden. [When corruption is to be successfully contained, it can only be achieved as a result of a long and necessarily complicated communication process; a process in which the freedom of the other and his/her rootedness in another situation are valued.] (p. 36, author's own translation])

\section{Navigating the private-public dichotomy in a way that is committed to the renewal of society}

Another vital theologically rooted factor that needs to be reckoned with in re-orienting the own thinking regarding truthful participation in society entails the own view on the relationship between private and public spheres. Christian communities should always ask themselves to what extent their views on their presence in this world are potentially isolating themselves from the full impact that they are called to have on their environment and specific locality. A dichotomy between what is conceptualised to be 'spiritual', on the one hand, and 'material', on the other hand, can lead Christians to associate the act of growing closer to God spiritually with withdrawing themselves from this world. They can become cynical about the material presence of the church in this world as if the idea of a so-called 'Christian nation' is necessarily fraught with superficiality and inauthenticity. A discontinuation between the 'present world' and the 'coming world' and a perceived distance between the immediacy of the own private concern and the remoteness of public concern can have a limiting effect that severely impede the impact of presence in civil society.

In a liberal democratic environment where state and religion tends to be separated, religion can allow itself to be drawn into a private sphere of only protecting the interests of its own circle. This may lead to a retreat from public life altogether, to isolated forms of religion, which do not feel urged to play an active role in a plural democratic society as long as they are left alone and can be 'free' to continue as they are. Exercising the prerogative to incorporate traditional, well-settled beliefs into the own endemic expression of Christianity (cf. Kaba 2005:559) can become so overwhelmingly important that the need to connect with ecumenical Christianity as well as express the public role in Western-style civic-society platforms can become less and less pronounced. This can result in a diminishing role for religion in civil society or even end up in the formation of exclusivist enclaves that may at some stage begin to play a counter-productive role in society when they feel threatened (Cochrane 2004:231).

An eschatological view that connects the kingdom values of the coming age with renewal of all spheres of life in this age is needed for a committed engagement with issues like endemic corruption in the demanding dialogical platforms of civil society.

\section{Conclusion}

Challenges surrounding the deeply rooted prevalence of corruption present an important test case for the competence of Christian traditions to re-orientate themselves regarding their role in the contemporary South-African civil society. The realignment of the prophetic voice and the revitalisation of the transformative presence in society need to be anchored in a profound and far-reaching theological reorientation. From the practical-theological reflection in this article the following final conclusion can be drawn regarding the extent of this much-needed theological re-orientation: Tension fields that involve critical and constructive action in a situation of endemic corruption cannot be authentically negotiated without the own presence being ridden from potential corruptive elements like hidden exclusivity, halfhearted concern and compromise.

\section{Acknowledgements Competing interests}

The author declares that he has no financial or personal relationships which may have inappropriately influenced him in writing this article.

\section{References}

Ahrens, T., 2011, 'Zum Antikorruptionsdiskurs in den evangelischen Missionswerken', in O. Rehren, O. Boersma, M. Biehl \& M. Keiper (eds.), Korruption und Transparenz: Rechenschaft in ökumenischen Beziehungen, pp. 26-41, Evangelisches Missionswerk in Deutschland, Hamburg.

Baker, C.R. \& Reader, J., 2009, 'Mapping the new theological space: From blurred encounters to thresholds of transformation', in J. Reader \& C. R. Baker (eds.) Entering the new theological space: Blurred encounters of faith, politics and community, pp. 219-229, Ashgate, Farnham.

Bediako, K., 2005, 'Christian witness in the public sphere: Some lessons and residual challenges from the recent political history of Ghana', in L. Sanneh \& J.A. Carpenter (eds.), The changing face of Christianity: Africa, the West, and the world, pp. 117-132, Oxford University Press, Oxford. http://dx.doi. org/10.1093/0195177282.003.0007

Blundo, G. \& de Sardan, J.-P.O., 2006, Everyday corruption and the state: Citizens and public officials in Africa, David Philip, Cape Town.

Boesak, A.A., 2005, The tenderness of conscience: African renaissance and the spirituality of politics, Sun Press, Stellenbosch.

Bompani, B., 2008, 'African Independent Churches in post-apartheid South Africa: New political interpretations', Journal of Southern African Studies 34(3), 665-677. http://dx.doi.org/10.1080/03057070802259928

Bongmba, E.K., 2006, Dialectics of transformation in Africa, Palgrave MacMillan, London. http://dx.doi.org/10.1057/9781403984586

Bosch, D.J., 1991, 'Church perspectives on the future of South Africa', in L. Alberts \& F. Chikane (eds.), The road to Rustenburg: The church looking forward to a new South Africa, pp. 129-139, Struik Christian Books, Cape Town.

Burchardt, M., 2013, 'Faith-based humanitarianism: Organizational change and everyday meanings in South Africa', Sociology of Religion 74(1), 30-55. http:// dx.doi.org/10.1093/socrel/srs068

Chabal, P. \& Daloz, J.-P., 1999, Africa works: Disorder as political instrument, James Currey, Oxford.

Cochrane, J.R., 2004, 'Research challenges on religion in South Africa', in D. Chidester, A. Tayob \& W. Weisse (eds.), Religion, politics and identity in a changing South Africa, pp. 225-240, Waxmann, Münster.

Coertzen, P., 2008, 'Grappling with religious differences in South Africa: A draft for a charter of religious rights', Brigham Young University Law Review 2008(3), 779-806.

De Freitas, S., 2005, 'The constitutional dynamic of civil society and the role of the churches in South Africa', Acta Academica 37(2), 21-51.

De Gruchy, J.W., 2004, 'From political to public theologies: The role of theology in public life in South Africa', in W.F. Storrar \& A.R. Morton (eds.), Public theology for the 21st century: Essays in honour of Duncan B. Forrester, pp. 45-62, T \& T Clark, London. 
De Villiers, D.E., 2008, 'The interdependence of public witness and institutional unity in the Dutch Reformed family of churches', Verbum et Ecclesia 29(3), 728-743. http://dx.doi.org/10.4102/ve.v29i3.27

Fioramonti, L. \& Fiori, A., 2010, 'The changing roles of civil society in democratization: Evidence from South Africa (1990-2009) and South Korea (1987-2009)', African and Asian Studies 9(1), 83-104. http://dx.doi. org/10.1163/156921010X491272

Fourie, W. \& Van Rooi, L., 2009, 'Geskeidenheid binne die familie van NG Kerke en die stryd om 'n menswaardige Suid(er)-Afrika: Enkele implikasies', Nederduits Gereformeerde Teologiese Tydskrif 50(1/2), 85-93.

Führding, S., 2013, 'Religion, privacy and the rise of the modern state', Method and Theory in the Study of Religion 25(2013), 118-131. http://dx.doi.org/10.1163/ 15700682-12341251

Hendriks, J. \& Erasmus, J., 2001, 'Interpreting the new religious landscape in postapartheid South Africa', Journal of Theology for Southern Africa 109(1), 41-65.

Hendriks, J. \& Erasmus, J., 2005, 'Religion in South Africa: The 2001 population census data', Journal of Theology for Southern Africa 121(1), 88-111.

Herderlike brief: Sinodesitting Ned. Geref. Kerk in Noord-Kaapland, 2015, besigtig op 23 March 2015, from http://ngkok.co.za/kennisg/201508/noordkaap.pdf.

Hermans, C.A.M., 2005, 'A pragmatic practical theology as public theology', in E. Graham \& A. Rowlands (eds.), Pathways to the public square: Practical theology in an age of pluralism, pp. 219-228, LIT Verlag, Münster. [International Academy of Practical Theology, Manchester 2003]

Hyslop, J., 2005, 'Political corruption: Before and after apartheid', Journal of Southern African Studies 31(4), 773-789. http://dx.doi.org/10.1080/03057070500370555

Immink, F.G., 2005, Faith: A practical theological reconstruction, Eerdmans, Grand Rapids.

Kaarsholm, P., 2009, 'Public spheres, hidden politics and struggles over space: Boundaries of public engagement in post-apartheid South Africa', Social Dynamics 35(2), 411-422. http://dx.doi.org/10.1080/02533950903076501

Kaba, A.J., 2005, 'The spread of Christianity and Islam in Africa: A survey and analysis of the numbers and percentages of Christians, Muslims and those who practice indigenous religions', Western Journal of Black Studies 29(2) 553-570.

Konieczny, M.E., Lybarger, L.D. \& Chong, K.H., 2012, 'Theory as a tool in the social scientific study of religion and Martin Riesebrodt's The promise of salvation', Journal for the Scientific Study of Religion 51(3), 397-411. http://dx.doi.org/10.1111/ for the Scientific Study of
j.1468-5906.2012.01663.

Kuperus, T., 2011, 'The political role and democratic contribution of churches in post-apartheid South Africa', Journal of Church and State 53 (2), 278-306. http://dx.doi.org/10.1093/jcs/csr030

Lehman, H.P., 2008, 'The emergence of civil society organizations in South Africa', Journal of Public Affairs 8, 115-127. http://dx.doi.org/10.1002/pa.288

Lodge, T., 2014, 'Neo-patrimonial politics in the ANC', African Affairs 113(450), 1-23. http://dx.doi.org/10.1093/afraf/adt069

McMullen, S., 2010, 'A new paradigm for the study of religion: A re-examination', Implicit Religion 13(1), 3-16. http://dx.doi.org/10.1558/imre.v13i1.3
Meiring, P.G.J., 2010, 'The influence of Calvinism on the South African Council of Churches', In die Skriflig, Supplement 3, 313-328. http://dx.doi.org/10.4102/ids. v44i4.196

Mbaku, J.M., 2007, Corruption in Africa: Causes, consequences and cleanups, Lexington Books, Lanham.

Naidoo, V., 2013, 'The politics of anti-corruption enforcement in South Africa', Journa of Contemporary African Studies 31(4), 523-542. http://dx.doi:10.1080/02589001. 2013.839369

Nkandla in the wind: Why the string of corruption scandals at the top is so disquieting 2014, The Economist, 12 April, viewed 9 July 2014, from http://www.economist. com.nwulib.nwu.ac.za/printedition/2014-04-12

Optog na parlement: Godsdiensleiers kap Zuma oor korrupsie, 2014, Die Burger, 20 April, viewed 16 August 2014, from http://www.dieburger.com/nuus/2014-04-20godsdiensleiers-kap-zuma-oor-korrupsie

Oxford Dictionaries, n.d. viewed 19 March 2015, from http://www.oxforddictionaries. com/definition/english/Scylla

Phiri, I., 2001, Proclaiming political pluralism: Churches and political transitions in Africa, Praeger Publishers, Cape Town.

Pieterse, H.J.C., 2000, 'Where have all the prophets gone?: Prophetic silence and the incapacity of religions to take us forward', in C.W. du Toit (ed.), Violence, truth and prophetic silence: Religion and the quest for a South African common good, pp. 82-97, Research Institute for Theology and Religion (UNISA), Pretoria.

Pleizier, T., 2010, Religious involvement in hearing sermons: A grounded theory study in empirical theology and homiletics, Eburon Academic Publishers, Delft.

Rule, S., 2007, 'Religiosity and quality of life in South Africa', Social Indicators Research 81, 417-434. http://dx.doi.org/10.1007/s11205-006-9005-2

Statistics South Africa, 2004, Primary tables South Africa: Census '96 and 2001 compared, Statistics South Africa, Pretoria, viewed 16 July 2014, from http://www. statssa.gov.za/census01/html/RSAPrimary.pdf [Report No. 03-02-04 (2001)].

Strauss, P.J., 2010, 'Eenheid in die NG Kerkfamilie: Waar staan die NG Kerk?', Nederduits Gereformeerde Teologiese Tydskrif 51(3/4), 135-142.

The Pew Forum, n.d., viewed 04 July 2014, from http://www.pewforum org/2009/04/23/religion-in-south-africa-15-years-after-the-end-of-apartheid/

Theron, P.F., 2008, 'From moral authority to insignificant minority: The precarious state of the Dutch Reformed Church in a post-apartheid South Africa', Journal of Reformed Theology 2(1), 228-239. http://dx.doi.org/10.1163/156973108X333722

Theron, P.F., 2012, Belhar - Geweeg, Kraal Uitgewers, Pretoria.

Venter, D., 2004, 'What is sociology that religionists should be mindful of it?: The relevance of the sociology of religion for studying change in South Africa', in D. Chidester, A. Tayob \& W. Weisse (eds.), Religion, politics and identity in a changing South Africa, pp. 183-206, Waxmann, Münster.

Vorster, N., 2013, 'Christianity and secularisation in South Africa: Probing the possible link between modernization and secularisation', Studies in World Christianity 19(2), 141-161. http://dx.doi.org/10.3366/swc.2013.0049

Zalanga, S., 2010, 'Religion, economic development and cultural change: The contradictory role of Pentecostal Christianity in sub-Saharan Africa', Journal of Third World Studies XXVII(1), 43-62. 